\title{
Participatory mapping to identify indigenous community use zones: Implications for conservation planning in southern Suriname
}

\author{
Sara O.I. Ramirez-Gomez ${ }^{\mathrm{a}, \mathrm{b}, \mathrm{c}, *}$, Greg Brown ${ }^{\mathrm{d}}$, Pita A. Verweij ${ }^{\mathrm{b}}$, René Boot ${ }^{\mathrm{e}, \mathrm{f}}$ \\ a Conservation International Suriname. 20 Kromme Elleboog Straat, Paramaribo, Suriname \\ b Copernicus Institute of Sustainable Development, Faculty of Geosciences, University of Utrecht, 3584 CS Utrecht, The Netherlands \\ c Tropenbos International Suriname Prof. Dr. Ruinardlaan, Paramaribo, Suriname \\ d School of Geography, Planning and Environmental Management, The University of Queensland, QLD 4072, Australia \\ e Tropenbos International, 6701 AN Wageningen, The Netherlands \\ ${ }^{\mathrm{f}}$ Ecology and Biodiversity Group, Department of Biology, Faculty of Science, Utrecht University, 3584 CH Utrecht, The Netherlands
}

\section{A R T I C L E I N F O}

\section{Article history:}

Received 27 March 2015

Received in revised form

29 November 2015

Accepted 29 November 2015

\section{Keywords:}

Participatory mapping

Community use zones

Landscape ecology

Ecosystem services

Indigenous conservation

\begin{abstract}
A B S T R A C T
Large-scale development projects often overlap forest areas that support the livelihoods of indigenous peoples, threatening in situ conservation strategies for the protection of biological and cultural diversity. To address this problem, there is a need to integrate spatially-explicit information on ecosystem services into conservation planning. We present an approach for identifying conservation areas necessary to safeguard the provision of important ecosystem services for indigenous communities. "Community use zones" (CUZs) were generated using participatory mapping methods that identify place values indicating significant hotspots for ecosystem services. Using principles from landscape ecology, these areas are buffered to provide connectivity and to delineate ecosystem service delivery areas. We demonstrate the use of CUZs for five villages in southern Suriname ( $n=191$ participants) to inform the South Suriname Conservation Corridor project. The mapped data reveal overlapping hotspots for different ecosystem services depicting multifunctional landscapes that provide an empirical foundation for delineating CUZs. In the absence of legal and traditional land rights for indigenous people, CUZs based on the provision of ecosystem services provide a defensible, spatially explicit approach for integrating indigenous needs into regional conservation plans in southern Suriname. We discuss the utility of CUZ maps for promoting land tenure and security and as a basis for collaborative governance in indigenous and community-conserved areas (ICCAs).
\end{abstract}

(c) 2015 Elsevier GmbH. All rights reserved.

\section{Introduction}

The livelihood and wellbeing of 60 million indigenous people globally depend entirely on forest ecosystem services (Chao, 2012) such as food, water, building materials, non-timber forest products and less tangible ones, often classified as cultural services, such as sense of place and cultural identity (Millennium Ecosystem Assessment, 2005). Because of their interdependency with forests, indigenous people see security of tenure over the forest territories that sustain their lives as a factor determining their existence (Larson, Barry, Ram Dahal, 2010). Incomes derived from ecosystem goods, such as wild foods (e.g., fruits, nuts, fish, game) and raw materials (fibers, resins, timber, and non-timber forest products) play a critical role in wellbeing by enabling vulnera-

\footnotetext{
* Corresponding author at: Leysweg 14, P.O. Box 4194 Paramaribo, Suriname. E-mail address: soi.sararamirez@gmail.com (S.O.I. Ramirez-Gomez).
}

ble forest-dependent people to obtain food and other important goods and services (Fisher et al., 2014; Poppy et al., 2014; Poppy, Jepson, Pickett, \& Birkett, 2014). Likewise, areas representing cultural values (e.g., sacred places, areas important for recreation) play a less tangible but important role because they are often safeguarded by local resource management strategies that simultaneously safeguard the supply of other ecosystem services (ES) such as pollination, fodder, and biodiversity (Berkes, 2012; Fabricius, Folke, Cundill, \& Schultz, 2007).

Community management of forests in the tropics can provide for long-term maintenance of forest cover (Porter-Bolland et al., 2012) while local participation in forest governance institutions is strongly associated with positive forest outcomes (Persha, Agrawal, \& Chhatre, 2011). Specifically, the role of indigenous communities in conservation has been acknowledged by international fora such as the UN Convention on Biological Diversity (CBD) (Kothari et al., 2014). Yet, a critical issue in the sustainable management of forest resources in the tropics is the status of land tenure and property 


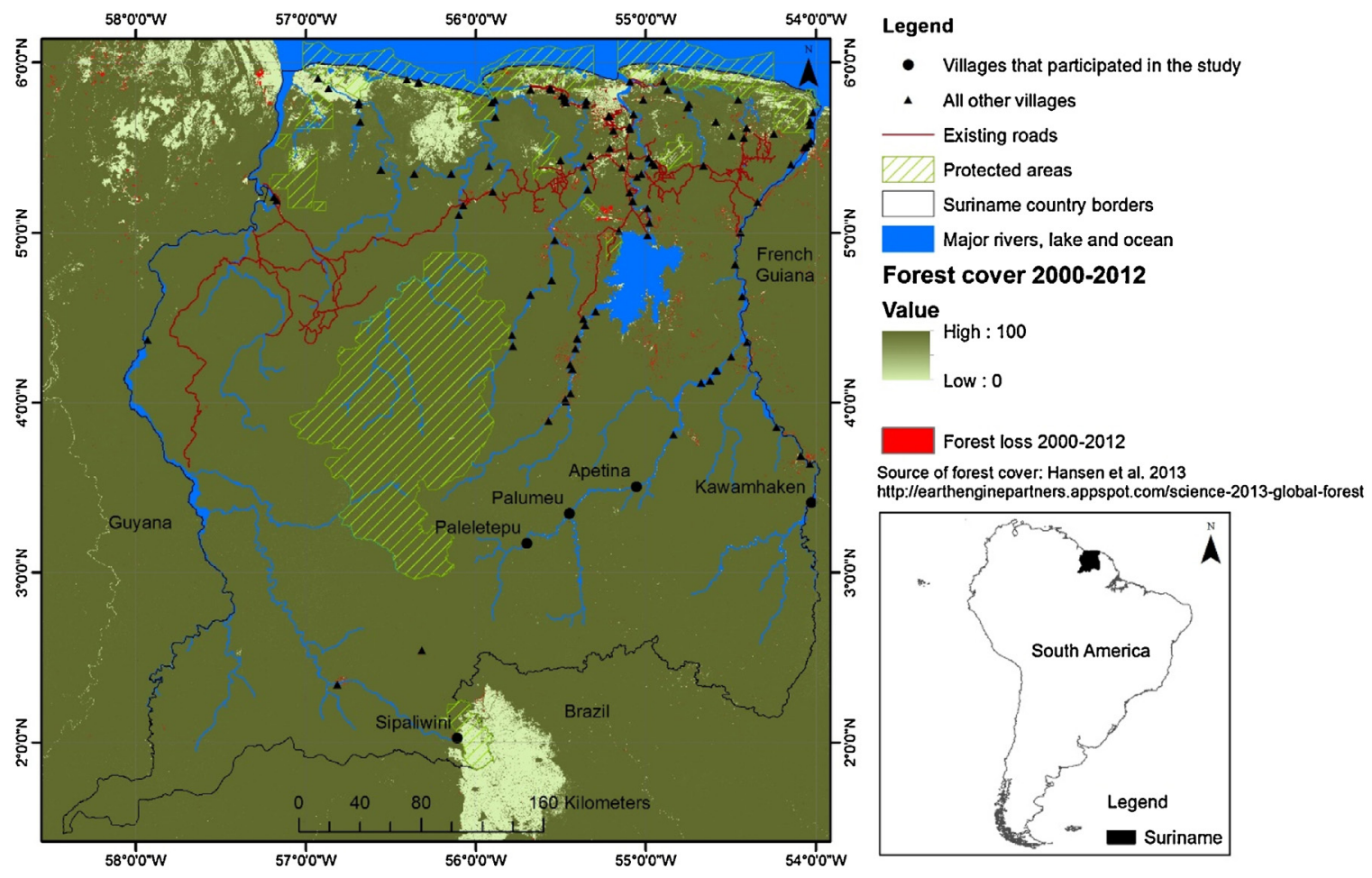

Fig. 1. Location and geographic context of the communities that participated in this study.

rights that enable access to livelihood resources and provide security from outside threats (Bennett \& Sierra, 2014; Fisher et al., 2014; Chapin et al., 2010). In the absence of land tenure security, an effective system of stewardship in indigenous peoples' regions can be undermined by both development and conservation efforts (Arnot, Luckert, Boxall, 2011; Schwartzman \& Zimmerman, 2005).

But long-term conservation outcomes cannot be guaranteed through property rights, community-based conservation, or the establishment of protected areas (Andrade \& Rhodes, 2012) alone. In practical terms, conservation has a spatial outcome, and without spatially-explicit boundaries, conservation becomes meaningless because there is no baseline to assess the impact of anthropogenic influences or to measure success or failure (Cumming, 2011; Daily et al., 2009). Especially in remote and data scarce regions where indigenous territories are not clearly defined or demarcated, and where there is no spatially-explicit information about the importance of areas to indigenous communities, investment plans for infrastructure, mining, and other extractive activities may conflict and undermine indigenous peoples' wellbeing. In the absence of adequate information regarding land use needs, nature conservation plans may inadvertently limit access for indigenous peoples to locations with cultural, symbolic, and livelihood value (Willemen, Drakou, Dunbar, Mayaux, \& Egoh, 2013; Lele, Wilshusen, Brockington, Seidler, \& Bawa, 2010; Daily et al., 2009; Cowling et al., 2008; Chan, Shaw, Cameron, Underwood, \& Daily, 2006). New information is required to estimate the shape and size of areas necessary to maintain the livelihoods of indigenous peoples, but the demarcation and zoning of these areas is hindered by gaps in spatial layers of socio-ecological information (Bernard, Barbosa, \& Carvalho, 2011; McLain et al., 2013).

The growing dependence on visualization tools for managing the impacts of land use on ecosystem services (Pagella \& Sinclair, 2014) has created the need for maps that communicate conservation and management needs more effectively (De Groot, Alkemade, Braat, Hein, \& Willemen, 2010; Egoh et al., 2007). And there is demand for visual tools that better integrate stakeholder per- ceptions and values into resource and environmental planning processes (Brown \& Fagerholm, 2014; McLain et al., 2013; Schägner, Brander, Maes, \& Hartje, 2013; Bryan, Raymond, Crossman, \& Macdonald, 2010; Nassauer \& Opdam, 2008). The integration of ES into spatial landscape planning (Crossman et al., 2013; De Groot et al., 2010) is important to safeguard ES flows (Ban et al., 2013; Reyers et al., 2013; Carpenter et al., 2009; Cowling et al., 2008) and should include areas where ES are generated, delivered to users, and areas that connect ES sources with users (Villa, Voigt, Erickson, 2014; Syrbe \& Walz, 2012; Fisher, Turner, \& Morling, 2009).

Participatory mapping appears suitable for identifying provisioning and cultural ecosystem services (Brown, Weber, Zanon, \& de Bie, 2012) that are operationalized through the mapping of place values. The early typologies of place values developed for participatory mapping were called landscape values (Brown \& Reed, 2000) and subsequently relabeled as social values for ecosystem services (Sherrouse, Clement, \& Semmens, 2011) because the values represent end-products of ecosystem services at their interface with human well-being. The supporting rationale for linking place values with ecosystem services derive from interpreting place values as part of a 'structure-function-value chain' (Termorshuizen \& Opdam, 2009) where ecosystem functions become services when their benefits are valued by humans (Brown, 2013). As an alternative to the concept of ecosystem services, Fagerholm, Käyhkö, Ndumbaro, \& Khamis (2012) used the term landscape services, arguing it has more relevance to the way that local stakeholders act and perceive their environment. The terms ecosystem services and landscape services appear largely interchangeable and for the purposes of this study, we adopt the more widely used term ecosystem services as the end-product identified by the mapping of place values.

In this article, we apply participatory geographic information systems (PGIS) to identify hotspots of place values to inform systematic conservation planning. We apply the concept of service provision hotspots (SPH) developed by Palomo, Martín-López, Potschin, Haines-Young, \& Montes (2013) to indicate areas highly valued for their multi-functional character in providing social and 
ecological services. Following the conceptual framework of Syrbe and Walz (2012), we define service connecting areas (SCA) as the spatial connections between SPHs and indigenous village locations. The outer perimeter of these areas is considered the minimum area needed for managing multiple ecosystem services on which local livelihoods depend (Serna-Chavez et al., 2014). We define these areas as community use zones (CUZ). To describe these zones and provide a foundation for their management, we use landscape metrics to identify the spatial structure and distributional patterns of the SPH components (Brown \& Reed, 2012), and we apply landscape ecology principles relevant to reserve design (i.e., connectivity of landscape elements) (Bennett, 2003; Dramstad, Olson, Forman, 1996) to operationalize functional service connections (Syrbe \& Walz, 2012).

\subsection{The conservation context}

This participatory GIS (PGIS) study was conceived in 2011 by Conservation International Suriname (CIS) to provide empirical data for the proposed South Suriname Conservation Corridor (SSCC) whose purpose is to protect and sustainably manage circa 2 million hectares of tropical forests and the headwaters of Suriname's major rivers. The SSCC is at the heart of the largest connected block of forests in the world and would link protected areas in Guyana, Suriname, French Guiana, and northern Brazil. Southern Suriname is inhabited by indigenous peoples, the Trio and Wayana, who directly depend on the forests for their livelihoods. The PGIS project was designed to engage with local communities to collaboratively produce knowledge about indigenous values and to identify conservation management approaches that meet the needs of indigenous communities located in the SSCC.

The study addresses two research questions: (1) how can we delineate areas needed to maintain the delivery of ecosystem services that support livelihoods and wellbeing of indigenous communities in southern Suriname, a remote region where data are scarce? (2) Can multifunctional areas serve as the basis for spatial zoning that maximizes and protects the delivery of those services? The diversity of indigenous communities and ecosystems within the study area provide a good opportunity to demonstrate CUZ methods that can be applied to a range of social and ecological conditions. Further, traditional land rights are not officially recognized by Surinamese law and therefore indigenous communities lack both tenure security and secure access to life-sustaining resources. In southern Suriname, access to ecosystem services that contribute to indigenous wellbeing has been favored by the remoteness of the region, but these services are threatened by land uses such as gold mining (Canasur Gold, 2014) and planned infrastructure investments (Suriname Business Forum, 2010). In the absence of spatially-explicit information on the needs and aspirations of indigenous communities, the goals of the SSCC may be compromised. The identification of indigenous CUZs presented in this study can provide information for land use and conservation interventions that secure access to livelihood resources while supporting the selection of participatory governance approaches that account for spatial use territories.

\section{Study area}

Southern Suriname is defined here as the region in the southeast of the country between $56^{\circ} \mathrm{W}$ and $54^{\circ} \mathrm{W}$ longitude and $4^{\circ} \mathrm{N}$ and $2^{\circ} \mathrm{N}$ latitude (Fig. 1). The area is predominantly under high tropical forest with patches of seasonally inundated forest, savanna forest on rocky soil, and savanna with cerrado vegetation (Bánki \& Aguirre, 2011). The region is inhabited by Trio and Wayana indigenous communities, who live in the five villages of Sipaliwini, Pelelutepu,
Table 1

Characteristics of the PGIS participants per community.

\begin{tabular}{llc}
\hline Community & No. of participants & Population estimate \\
\hline Sipaliwini & 22 & 214 \\
Pelelutepu & 58 & 393 \\
Palumeu & 23 & 360 \\
Apetina & 69 & 262 \\
Kawemhakan & 19 & 82 \\
\hline
\end{tabular}

Palumeu, Apetina, and Kawemhakan. Their livelihoods are based on shifting cultivation, fishing, hunting and harvesting timber and non-timber forest products for subsistence and cash exchange. Some income is also derived from the small number of tourists visiting the communities. There are no accurate data on the population size of these villages, but unofficial reports estimate a total of 1311 people in the study area (Table 1) (Heemskerk \& Delvoye, 2007; Heemskerk, Delvoye, Noordam, \& Teunissen, 2006). These remote villages, located $300 \mathrm{~km}$ from the country's capital Paramaribo, are accessible only by plane or boat trip of several days along and across rivers, rapids, and small creeks. Within the study area, there is one protected area, the Sipaliwini Nature Reserve, an area of 77,500 ha.

\section{Methods}

\subsection{Place values}

The attributes to be mapped were developed together with the participants based on their personal experience and knowledge. The respondents were asked to make a list of the place features that were important to them which developed into a comprehensive list including several species of birds, frogs and turtles which they sell. The list also included fisheries, agricultural products, wild fruits, firewood, drinking water sources, materials to build houses and boats, fibers to make hammocks and kitchen utensils, places with traditional and spiritual value, sense of place, tourism, and recreation opportunities. These items were grouped by the participants into income generation, food, building materials, culture, recreation, drinking water (see Ramirez-Gomez, Brown, \& Tjon Sie Fat, 2013, for full details). Another place attribute was added by participants at a later stage in the mapping process to describe areas that are needed to support future generations.

The attributes identified by the participants were interpreted as a subset of place values in the typology developed by Brown and Reed (2000). This typology included 13 values: aesthetic; economic; recreation; life sustaining; learning; biological; spiritual; intrinsic; historic; future; subsistence; therapeutic; and cultural value. For this study, only future, cultural, economic, and subsistence values were used for mapping because we believed they best matched the perceptions of the participants (Table 2). The need for flexibility to tailor the mapping categories and terminology to the specific study context and population is a well-recognized principle in participatory GIS methods. Cultural value was locally adjusted to contain areas with traditional, spiritual, and recreation values such that the operational definition contained multiple cultural categories from the Millennium Ecosystem Assessment (MA, 2005). The aggregation of values under the cultural label emerged during validation of the typology with participants indicating that areas with traditional, spiritual, and recreation value were often the same. For example, Akijo Ituro rapids is a sacred site and a place to share food and drinks when traveling on a holiday trip. Participants indicated that combining separate cultural values into one category would make it easier for them to create and use the maps. The combined categories also constitute tacit recognition by the indigenous participants that some ecosystem services are spatially "bundled" in the landscape (Raudsepp-Hearne, Peterson, Bennett, 2010). 

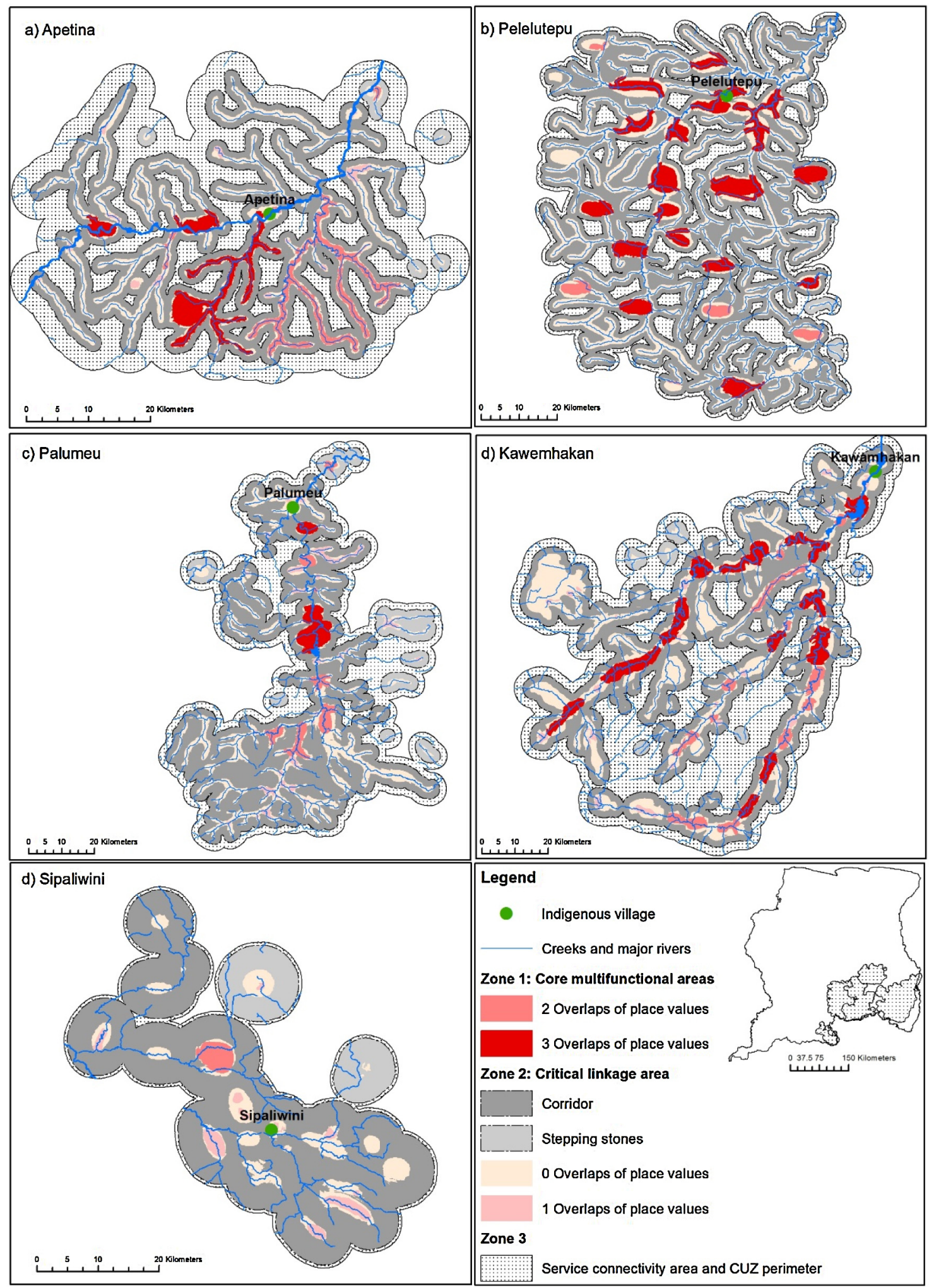

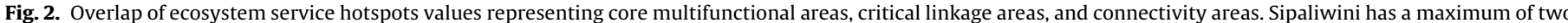

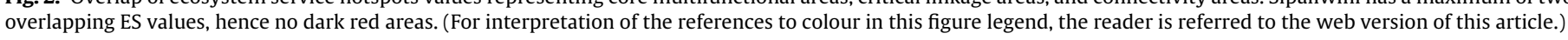

\subsection{Data collection}

Data collection was organized in participatory mapping (PGIS) workshops between January and November 2012 with 191 community members from the five indigenous villages that participated in this study. Respondents were selected on a volunteer basis bal- ancing local knowledge of the territory, gender, and age. Older people with detailed knowledge of the study area participated in the mapping activity with the assistance of a younger person. In the process we used a base map (size A1) that contained a digital elevation model (DEM) with 90 meters resolution obtained from the Shuttle Radar Topography Mission (http://srtm.csi.cgiar.org/ 


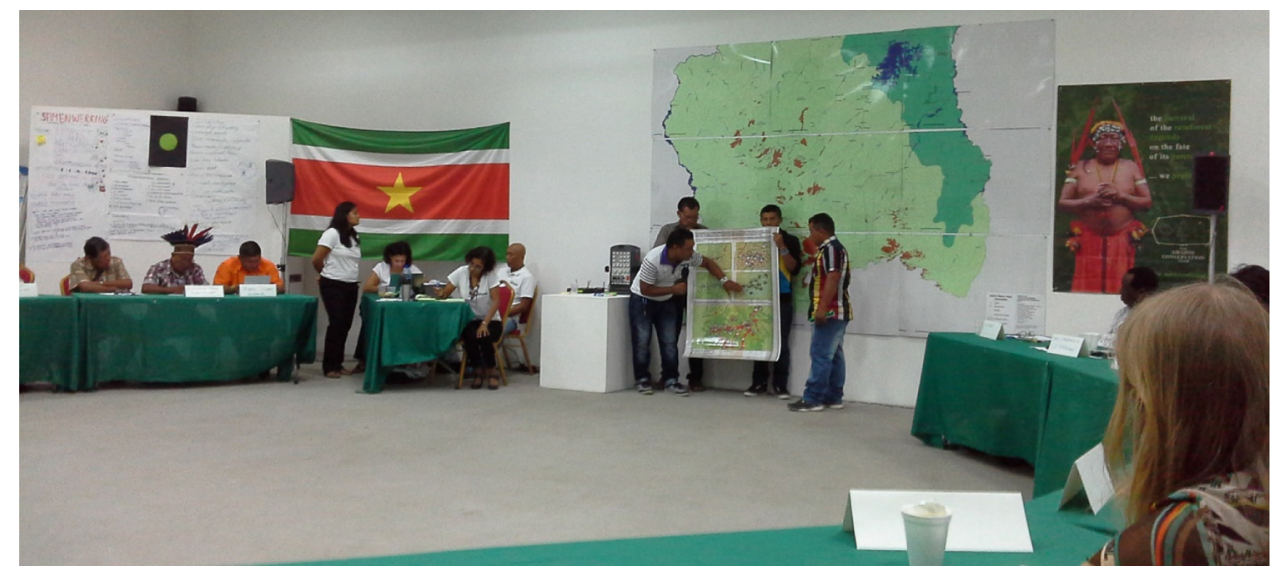

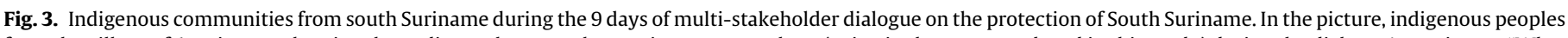

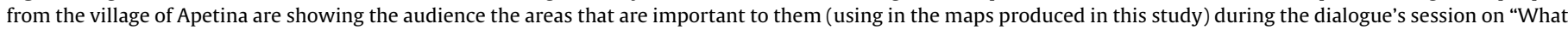
needs to be conserved and where" held in Paramaribo on February 23, 2015. Photo by Sara Ramirez-Gomez.

SELECTION/inputCoord.asp) and reclassified for two elevations: above and below $400 \mathrm{~m}$ to highlight mountain ranges and inselbergs which are important spatial referents for the indigenous communities in southern Suriname. The base map also included river, creeks, and village locations. The scale of the base maps varied from 1:100,000 to $1: 250,000$ depending on the area each community decided to map. One map was given per participant in each of the villages and using a different color for each place value, each villager drew polygons to indicate important locations on the map. Informants were allowed to mark as many places as they wanted, allowing overlap between areas.

\subsection{Hotspots of place values}

The mapping activities resulted in 191 individual participant maps containing multiple locations for four place values (cultural, economic, subsistence, future). These maps were digitized and stored as vector data in a geographic information system (GIS) (ArcGIS v.10) using a geographic grid as a reference. Layers of values were overlaid by applying a customized GIS tool (Ramirez-Gomez \& Martínez, 2013) that counts the number of overlapping polygons, resulting in density maps for each place value. For each value density map, we identified high concentrations of values that we defined as service provisioning hotspots ( $\mathrm{SPH}$ ) by applying a cut-off value equal to the upper third of the polygon density distribution, a cut-off heuristic implemented in other studies (e.g., Brown \& Pullar, 2012; Ramirez-Gomez et al., 2015). The final hotspot maps were validated with participants in community meetings and two copies of the final maps, as well as a digital version incorporating their comments, were returned to the communities (see Ramirez-Gomez et al., 2013, for more details).

\subsection{Analysis of spatial patterns of SPHs}

To examine the spatial characteristics of SPHs as landscape patches, we generated social landscape metrics as described by Brown and Reed (2012). These authors adapted landscape ecology metrics to social data to quantify the spatial attributes of human perception of place. In our study, we used Patch Analyst for ArcGIS (Rempel \& Carr, 2012) to calculate six social landscape metrics that measure the size, shape, number, and relative isolation of SPHs (Table 3). These metrics were selected to assist in the identification of appropriate buffer distances to achieve connectivity among SPHs and to assist in the delineation of CUZs that combine core SPHs with connectivity buffer zones.

\subsection{Spatial concurrence of service provisioning hotspots (SPH)}

To identify areas within the CUZs that have multifunctional qualities, we spatially intersected the SPH maps. Areas where more than one SPH spatially overlap were assumed to be multifunctional areas because ecosystem services that co-occur within an area are considered to be a surrogate for multiple ecosystem functions (Raudsepp-Hearne et al., 2010). To quantify and measure the degree of spatial association, we applied Jaccard's coefficient to the spatial data for each community. The coefficient was calculated for each pair of hotspots for each community as follows:

$$
J_{\mathrm{SPH} 1,2}=\frac{\mathrm{SPH} 1 \bigcap \mathrm{SPH} 2}{((\mathrm{SPH} 1 \bigcup \mathrm{SPH} 2)-(\mathrm{SPH} 1 \bigcap \mathrm{SPH} 2))}
$$

where SPH1 is the hotspot for a given place value (e.g., subsistence) and SPH2 is the hotspot for a different place value (e.g., culture). The numerator indicates the area of intersection between the pair of SPHs and the denominator indicates the difference between the union (sum) and intersection of the SPH areas.

\subsection{Identification of service connecting areas (SCA) and delineation of community use zones}

Although CUZs can be identified simply as the SPH multifunctional areas, we added additional buffers to SPH multifunctional zones, the justification being the need to provide linkages between the SPH multifunctional areas (Syrbe \& Walz, 2012). Thus, CUZs consist of two landscape components: (1) core multifunctional areas; and (2) connectivity linkages. Core multifunctional areas were operationalized by examining the number of SPH polygon overlaps and then selecting the top $50 \%$ as a cut-off to delineate core areas. To determine an appropriate spatial arrangement that serves the connectivity function of a CUZ, we considered the following landscape ecological principles related to connectivity and corridors (Bennett, 2003; Dramstad et al., 1996):

a) Landscape ecological functionality is dependent on an effective network of corridors connecting important nodes (core zones).

b) Continuous corridors are better than fragmented corridors (nearness is better than separation). Although not an optimal configuration, a series of small patches between large patches can serve as stepping stones in corridors if the distance between them is not too large. 
Table 2

Typology of place values as perceived by indigenous communities in southern Suriname.

\begin{tabular}{|c|c|c|}
\hline Place value & Description & Local activity/indicator \\
\hline Future & $\begin{array}{l}\text { Areas valued because they allow future } \\
\text { generations to know and experience the area } \\
\text { as it is now. }\end{array}$ & Mainly freshwater sources and fishing grounds. \\
\hline Cultural & $\begin{array}{l}\text { Areas valued because they hold spiritual value, } \\
\text { because they are meaningful to their } \\
\text { traditions, because they have aesthetic value } \\
\text { and because they are a good place to swim. }\end{array}$ & $\begin{array}{l}\text { River rapids, mountains, ancestral settlements, } \\
\text { caves, inselbergs. }\end{array}$ \\
\hline Economic & $\begin{array}{l}\text { Areas valued because they provide income } \\
\text { opportunities for local indigenous } \\
\text { communities from timber, fisheries, minerals } \\
\text { or tourism activities. }\end{array}$ & $\begin{array}{l}\text { Handicrafts made from Oenocarpus bacaba, } \\
\text { (Didimopanax morototoni), selling of birds } \\
\text { (such as Oryzoborus crassirostris, Oryzoborus } \\
\text { angolensis, Cotinga spp.), selling of reptiles } \\
\text { (Corallus caninus, Boa constrictor) and } \\
\text { amphibians (Dendrobatus tinctorius, } \\
\text { Ceratophrys varia, Bufo marinus). }\end{array}$ \\
\hline Subsistence & $\begin{array}{l}\text { Areas valued because they provide drinking } \\
\text { water, food, raw materials and fuel to sustain } \\
\text { the lives of local indigenous communities. }\end{array}$ & $\begin{array}{l}\text { Shifting cultivation, collection of firewood, } \\
\text { wild fruits, timber and thatch. Hunting areas, } \\
\text { fishing grounds. }\end{array}$ \\
\hline
\end{tabular}

Table 3

Landscape metrics applied (Farina, 2000).

\begin{tabular}{|c|c|c|}
\hline Landscape metrics & Abbreviation & Description \\
\hline Number of patches & NumP & The total number of patches of an ES value type. \\
\hline Mean Patch Size & MPS & $\begin{array}{l}\text { The total size of the area covered by patches of ES values, calculated as a simple arithmetical } \\
\text { mean. }\end{array}$ \\
\hline Mean patch shape index & MSI & $\begin{array}{l}\text { A standardized measure of patch shape, calculated for each patch of an ES value type, then } \\
\text { summed across all patches of the same type as a simple arithmetical mean. It equals } 1 \text { when } \\
\text { patches approach a circular shape. }\end{array}$ \\
\hline Mean Nearest Neighbor & MNN & $\begin{array}{l}\text { The Euclidean distance between patches of an ES value and its nearest neighbor summed } \\
\text { across all patches of the same ES value type, as a simple arithmetical mean. }\end{array}$ \\
\hline Percentage of landscape & ZLand & $\begin{array}{l}\text { The proportion of the landscape comprising a particular ES value type. We applied it to } \\
\text { estimate the proportion of the ES value within the CUZ. }\end{array}$ \\
\hline Total landscape area & TLA & The sum of areas of all patches of an ES value type in the landscape. \\
\hline
\end{tabular}

Table 4

Social landscape metrics applied for service provisioning hotspot values within each community use zone.

\begin{tabular}{|c|c|c|c|c|c|c|c|c|c|c|c|c|}
\hline \multirow[t]{3}{*}{ Community } & \multicolumn{12}{|c|}{ Typology of place values } \\
\hline & \multicolumn{3}{|l|}{ Future } & \multicolumn{3}{|l|}{ Culture } & \multicolumn{3}{|l|}{ Economic } & \multicolumn{3}{|c|}{ Subsistence } \\
\hline & $\begin{array}{l}\text { No. } \\
\text { Hotspots }\end{array}$ & $\begin{array}{l}\text { Mean } \\
\text { hotspot } \\
\text { size (ha) }\end{array}$ & $\begin{array}{l}\text { Percent } \\
\text { of CUZ }\end{array}$ & $\begin{array}{l}\text { No. } \\
\text { Hotspots }\end{array}$ & $\begin{array}{l}\text { Mean } \\
\text { hotspot } \\
\text { size (ha) }\end{array}$ & $\begin{array}{l}\text { Percent } \\
\text { of CUZ }\end{array}$ & $\begin{array}{l}\text { No. } \\
\text { Hotspots }\end{array}$ & $\begin{array}{l}\text { Mean } \\
\text { hotspot } \\
\text { size (ha) }\end{array}$ & $\begin{array}{l}\text { Percent } \\
\text { of CUZ }\end{array}$ & $\begin{array}{l}\text { No. } \\
\text { Hotspots }\end{array}$ & $\begin{array}{l}\text { Mean } \\
\text { hotspot } \\
\text { size (ha) }\end{array}$ & $\begin{array}{l}\text { Percent } \\
\text { of CUZ }\end{array}$ \\
\hline Apetina & 34 & 1,308 & 14.9 & 24 & 296 & 2.4 & 20 & 223 & 1.5 & 44 & 507 & 7.2 \\
\hline Pelelutepu & 88 & 1,731 & 21.6 & 34 & 1,680 & 8.1 & 31 & 1,034 & 4.6 & 160 & 514 & 11.7 \\
\hline Palumeu & 83 & 1,138 & 15.6 & 32 & 697 & 3.7 & 10 & 970 & 1.6 & 90 & 485 & 7.2 \\
\hline Kawemhakan & 88 & 856 & 8.5 & 38 & 2,695 & 11.6 & 32 & 1,900 & 6.9 & 53 & 1,516 & 9.1 \\
\hline Sipaliwini & - & - & - & 7 & 897 & 3.7 & 17 & 530 & 5.2 & 33 & 484 & 9.3 \\
\hline
\end{tabular}

a Community use zone.

c) Wide corridors are better than narrow corridors, so wherever possible, the width of linkages should be maximized to increase effectiveness.

d) Two or more corridor connections are better than one.

e) Additionally, connectivity can be achieved by creating a single compact or larger contiguous patch from small individual patches (Williams et al., 2005; Tischendorf \& Fahrig, 2000).

For the application of these principles in this study, we examined the mean nearest neighbor metric (MNN) of the patches to estimate the degree of isolation and to identify potential buffer distances that would ensure structural connectivity that minimizes gaps in patch linkages (Bennett, 2003). Accordingly, if the MNN was relatively large, we experimented with larger buffer distances. We visually inspected the results of multiple trials on buffer distances to determine whether the buffer resulted in compact linkage areas.
A similar buffering method was implemented by Serna-Chavez et al., (2014) who delineated spatial ES flow areas by applying the maximum threshold distance from the outer perimeter of the provisioning area.

CUZs were operationalized as consisting of three management zones. Zone 1 contains the core multifunctional areas (or nodes) while Zone 2 corresponds to the buffer distance needed to create compact linkages for the connectivity function. A third zone (Zone 3) was added to provide an area to protect the function of the network system (Baker, 1992; Batisse, 1982). This third zone was identified based on the "nearness" landscape ecology principle (principle (b) above) to ensure that isolated patches (i.e., stepping stones) were included in the connectivity network. The total size of each CUZ was determined by the total area contained within the perimeter of Zone 3. We call these zones core multifunctional areas, critical linkage areas, and service connecting areas respectively. 
Table 5

Jaccard's coefficients for measuring spatial overlap of place value hotspots for the five villages in Suriname.

\begin{tabular}{|c|c|c|c|c|}
\hline Apetina & Economic & Subsistence & Future & Cultural \\
\hline Economic & - & & & \\
\hline Subsistence & 0.12 & - & & \\
\hline Future & 0.06 & 0.34 & - & \\
\hline Culture & 0.56 & 0.13 & 0.07 & - \\
\hline Sipaliwini & Economic & Subsistence & Future & Cultural \\
\hline Economic & - & & & \\
\hline Subsistence & 0.21 & - & & \\
\hline Future & $\mathrm{N} / \mathrm{A}$ & $\mathrm{N} / \mathrm{A}$ & - & \\
\hline Culture & 0.17 & 0.18 & $\mathrm{~N} / \mathrm{A}$ & - \\
\hline Kawemhakan & Economic & Subsistence & Future & Cultural \\
\hline Economic & - & & & \\
\hline Subsistence & 0.24 & - & & \\
\hline Future & 0.07 & 0.12 & - & \\
\hline Culture & 0.16 & 0.28 & 0.06 & - \\
\hline Pelelutepu & Economic & Subsistence & Future & Cultural \\
\hline Economic & - & & & \\
\hline Subsistence & 0.30 & - & & \\
\hline Future & 0.05 & 0.12 & - & \\
\hline Culture & 0.51 & 0.37 & 0.06 & - \\
\hline Palumeu & Economic & Subsistence & Future & Cultural \\
\hline Economic & - & & & \\
\hline Subsistence & 0.19 & - & & \\
\hline Future & 0.03 & 0.20 & - & \\
\hline Culture & 0.42 & 0.34 & 0.07 & - \\
\hline
\end{tabular}

\section{Results}

\subsection{Spatial patterns of service providing hotspots (SPHs) by community}

The CUZs in the southern Suriname study region cover a total area of approximately 2.7 million hectares ( $\mathrm{Ha}$ ). Their average size is 532,410 ha. The landscape metrics for different communities show significant spatial variability, with some SPHs comprising a larger proportion of the total CUZ (Table 4). For example, in three villages, the most important SPHs in terms of percentage of CUZ coverage were those for future value, covering $21 \%$ of Pelelutepu CUZ, $15.6 \%$ of Palumeu CUZ, and $14.9 \%$ of Apetina CUZ. In the other two villages, proportionally the largest SPHs in areal terms were the SPH for culture in Kawemhakan CUZ (11.6\%) and the SPH for subsistence value in Sipaliwini CUZ (9.3\%). At the other extreme, the smallest SPH in terms of proportion of area of the CUZ was for economic value, except for Sipaliwini CUZ, where it was culture. The size and number of SPHs also varied by community. On average, SPHs of future value were the largest, while subsistence hotspots were the smallest and most numerous $(n=380)$. SPHs for economic value were fewest in number $(n=110)$.

\subsection{Spatial association between place values by community}

The spatial association between the different place values mapped by each community in the study area was quantified with Jaccard's coefficient (Table 5). In Apetina, Pelelutepu, and Palumeu, cultural and economic value had the highest degree of spatial association $(J=0.56,0.51$, and 0.42 respectively). In Apetina, future and subsistence values were moderately associated $(J=0.34)$, while in the other four villages, this spatial association was much lower. In Pelelutepu and Palumeu, cultural and subsistence had a moderate degree of spatial association ( $J=0.37$ and 0.34 respectively) whereas in Apetina, this spatial association was weak $(J=0.13)$. In Sipaliwini, the level of spatial association was weak, with cultural and subsistence having the highest level of spatial association $(J=0.18)$. With the exception of Apetina, future value areas had the lowest spatial concurrence with other place values throughout the study area.

\subsection{CUZ landscape metrics}

The number of core multifunctional patches (NumP) was largest in Kawemhakan $(n=25)$ and smallest in Sipaliwini $(n=1)$. There was relative uniformity in the mean patch size (MPS) of core multifunctional areas across the five communities, with an average patch size of about 2500 hectares. However, the core areas in all communities were irregularly shaped patches (MSI), with the most elongated patches found in Apetina. Rivers and waterways strongly influenced the shape of mapped areas in all communities except Sipaliwini (Fig. 2). The mean nearest neighborhood statistic (MNN) shows that core areas were most isolated in Pelelutepu and Palumeu, and most proximate in Kawemhakan. The MNN statistic in the connectivity zone reveals that Sipaliwini had the most distant patches and hence need for a larger buffer to connect the multifunctional areas (Fig. 2e), while Palumeu and Kawemhakan require moderate size buffers to connect core areas (Fig. $2 \mathrm{~d}$ and 2e). After buffering the core areas to attain a linkage area (Zone 2), some patches remained isolated, especially in Apetina, Palumeu and Kawemhakan. These patches may be considered "stepping stones" (Bennett, 2003), so extending the buffer over longer distances was required to connect these areas (Zone 3 ) to form the CUZs (Table 6).

\section{Discussion}

This case study has demonstrated how the participatory mapping of place values can be used to estimate the area needed to provide the ecosystem services on which local livelihoods depend. Mapped place values were analyzed and assembled into landscape components called core provisioning areas, linkage, and connectiv-

Table 6

Social landscape metrics applied to landscape components within the Community use Zones (CUZs).

\begin{tabular}{|c|c|c|c|c|c|c|c|c|c|c|c|c|c|}
\hline \multirow[t]{2}{*}{ Community } & \multicolumn{5}{|c|}{ Zone 1: Core multifunctional areas } & \multicolumn{6}{|c|}{ Zone 2: Critical linkage area } & \multicolumn{2}{|c|}{$\begin{array}{l}\text { Zone 3: Service } \\
\text { connectivity area }\end{array}$} \\
\hline & NumPa & $\begin{array}{l}\text { MPS }^{b} \\
\text { (ha) }\end{array}$ & $\mathrm{MSI}^{\mathrm{c}}$ & $\begin{array}{l}\mathrm{MNN}^{\mathrm{d}} \\
(\mathrm{m})\end{array}$ & $\begin{array}{l}\text { Total } \\
\text { core area } \\
\text { (ha) }\end{array}$ & NumP & MPS (ha) & MSI & $\operatorname{MNN}(\mathrm{m})$ & $\begin{array}{l}\text { Buffer } \\
\text { distance } \\
(\mathrm{m})\end{array}$ & $\begin{array}{l}\text { Buffer } \\
\text { area (ha) }\end{array}$ & $\begin{array}{l}\text { Buffer } \\
\text { dis- } \\
\text { tance }(m)\end{array}$ & $\begin{array}{l}\text { Total CUZ } \\
\text { area }\end{array}$ \\
\hline Apetina & 7 & 2,759 & 2.76 & 3,041 & 11,311 & 502 & 69 & 1.68 & 165 & 1,000 & 159,160 & 3,000 & 297,819 \\
\hline Pelelutepu & 22 & 2,608 & 1.83 & 4,500 & 57,369 & 466 & 508 & 1.76 & 158 & 1,200 & 563,323 & 1,000 & 704,122 \\
\hline Palumeu & 9 & 2,464 & 1.71 & 5,867 & 22,173 & 474 & 208 & 1.66 & 465 & 2,000 & 428,144 & 2,000 & 606,816 \\
\hline Kawemhakan & 25 & 2,592 & 1.74 & 1,479 & 64,796 & 438 & 355 & 1.60 & 395 & 2,000 & 546,700 & 2,600 & 881,512 \\
\hline Sipaliwini & 1 & 2,277 & 1.25 & 1 & 22,173 & 92 & 224 & 1.58 & 989 & 4,000 & 155,909 & 500 & 171,781 \\
\hline
\end{tabular}

a Number of patches.

b Mean patch size.

c Mean shape index.

d Mean nearest neighbor. 
ity areas as suggested by Serna-Chavez et al. (2014) and Syrbe and Walz (2012). The delineation of these zones can guide development and planning for indigenous communities and conservation initiatives such as the South Suriname Conservation Corridor. The novel application of landscape ecological principles to indigenous settlements and patterns of land use operationalizes a multifunctional landscape planning approach (Reyers et al., 2013) that accounts for the spatial extent of local livelihoods and areas of concern for the mitigation of negative impacts from encroaching human activities (Williams et al., 2005). For example, the use of patch connectivity as a guiding CUZ principle prevents spatial disconnection that can hamper spatial flow paths for ecosystem service delivery (SernaChavez et al., 2014; Bagstad, Johnson, Voigt, \& Villa, 2013; Syrbe \& Walz, 2012).

The spatial association between place values mapped in this study (i.e., subsistence, cultural, future, and economic) revealed that some values exhibit bundling, i.e., are spatially coincident and frequently appear together (Raudsepp-Hearne et al., 2010). For example, economic and subsistence values showed modest levels of spatial concurrence in all villages and may be attributed to livelihood activities such as fishing that are done for subsistence as well as income generation (Ramirez-Gomez et al., 2013). Economic and cultural value showed the largest spatial concurrence in the three villages of Apetina, Palumeu and Pelelutepu, and is also attributable to common livelihoods in these villages. For example, villagers in Palumeu and Apetina derive an important part of their livelihood from income related to tourism and attractions located in areas with significant cultural values. Similarly, in Pelelutepu, areas with high cultural value, described as special places by the local community, overlap with areas where wildlife provide local sources of income (Ramirez-Gomez et al., 2013). In contrast, future values were not significantly spatially concurrent with the other mapped values. Local narratives about places with future value indicate current low use, but the indigenous communities view these areas as functional "reserves" for subsistence and income-related resources that will support future livelihoods.

SPHs with two or more overlapping ecosystem services (red areas in Fig. 2) represent a relatively small proportion of the total area used and valued by the five communities. The delineation of CUZs based exclusively on SPHs (i.e., Zone 1 core areas) would greatly underestimate the geographic area used by the indigenous communities. Expanding SPH areas through linkage buffers (i.e., Zone 2 critical linkage areas) provides a more realistic assessment of the actual area needed by the communities to sustain their livelihoods and important cultural areas. Heuristic approaches to determine buffer distances can enhance the level of connectivity (Fahrig, 2001; Opdam \& Wascher, 2004; Tischendorf \& Fahrig, 2000) and we therefore trialed a number of buffer distances in this study.

The delineation of CUZs based on core and connectivity zones was insufficient to fully capture the geographic complexity of community needs in the region. The mapped areas in Fig. 2 reveal distinctive spatial patterns of land use by different communities, with the communities of Apetina, Palumeu, Pelelutepu, and Kawamhaken being highly dependent on riverine systems, as shown by SPHs located along rivers, while the community of Sipaliwini was much more dependent on the savanna environment. The service connecting areas (Zone 3) fill the spatial gaps between the network of rivers and waterways. Although these areas are not used intensively by the communities, largely because of the difficulty of access and transport in the study region, they nonetheless provide supporting ecosystem functions (e.g., soil retention, water purification) that help sustain the biological productivity of the riparian areas. Zone 3 areas can be described as "indirect" community use areas. Thus, the CUZ mapping approach described in this study is best characterized as providing an estimate of the areas needed by indigenous people in the region.

\subsection{Implications for conservation planning in southern Suriname}

Pragmatically, having delineations of CUZs in the southern Suriname region increases the likelihood that land use and conservation plans will reflect indigenous peoples' needs. The identification of CUZs is a modest step toward providing decision makers in Suriname with information that may help integrate protection of indigenous livelihoods, the promotion of appropriate economic development, and the identification of conservation opportunities in a region characterized by weak institutions and a need for capacity building. In the absence of legal traditional land rights for indigenous people in Suriname, CUZs derived from place values that identify important ecosystem services provide a defensible, spatially explicit approach for integrating indigenous needs into regional conservation plans in southern Suriname. Based on the results, we suggest three major implications of the CUZ approach for conservation planning: (1) as an empirical foundation for promoting and advocating land tenure and security; (2) as a basis for a collaborative governance approach to indigenous and communityconserved areas (ICCAs) and, in the specific context of the SSCC; and (3) a tool for allowing a sensible zonation plan that considers multiple stakeholders needs.

The CUZs represent an important communication tool for indigenous communities in the study area on issues related to their territory. For example, during the Multi-stakeholders Dialogue on the Protection of South Suriname, ${ }^{1}$ the indigenous communities used the maps produced during the first part of the study (see Ramirez-Gomez et al., 2013) to show the audience the areas that are important to them and that should be considered when designing the SSCC (Fig. 3). Thus, identification of CUZs can facilitate more effective involvement and compliance with indigenous people's right to free prior informed consent (FPIC) vis à vis proposed conservation interventions and exploitative concessions in indigenous territories. This is very important in contexts like Suriname where indigenous communities lack national level legal recognition and support.

CUZs can also provide the basis for a management approach grounded in sound governance principles and participation that encourages resource stewardship, nature protection, sustainable land use, and a right based approach to conservation (Campese, 2009). Specifically, information about CUZs in southern Suriname can support ongoing national dialogues about ICCAs (VIDS, 2012) or other collaborative governance systems by providing estimates of the areas used by indigenous communities to maintain traditional ways of life (Bernard et al., 2011). In other countries (e.g., Bolivia), this information is less urgent in ongoing ICCA dialogues because indigenous communities have clearly defined the extent of their territories (Miranda \& Vadillo, 2012). Currently, de facto ICCAs exist in southern Suriname (VIDS, 2012) as a result of customary laws, traditions, and spirituality, while other de facto ICCAs have been designated as an incentive for earning income from ecotourism. The identification of CUZs can help leverage co-management agreements, such as ICCAs, although these agreements will require supporting legislation (Kothari et al., 2014; Oviedo, 2006; VIDS, 2012). Similarly, current conservation planning projects, like the SSCC, should incorporate the expectations of indigenous communities for their livelihoods and cultural well-being. As noted by (Colchester, 1998), conservation should not rely on state bureau-

\footnotetext{
1 (http://www.conservation.org/NewsRoom/pressreleases/Pages/Guardiansof-the-Forest-Indigenous-Peoples-Take-Action-to-Conserve-Nearly-Half-ofSuriname.aspx).
} 
cracies to defend isolated, protected areas of high biodiversity. Conservation and biodiversity protection must occur within larger landscapes occupied by human beings that care about the environment and the wellbeing of future generations (Colchester, 2000).

\subsection{Limitations of the CUZ approach}

There is a tendency for spatial analysis to over simplify the complexity of real-world application. For example, in the case of Kawemhakan, the resulting CUZ is the largest in area, but has the smallest population. This complexity exists in other indigenous territories across the Amazon where indigenous peoples, especially the young, are migrating to cities or frontier zones where they can better access education, health care, and commodities (Alexiades, 2013; Pérez-Llorente et al., 2013). Therefore, when determining the size, management, and characteristics of proposed CUZs, data on population size, growth, and out-migration should be incorporated, although this could prove difficult in resource and data-scarce regions like southern Suriname.

Effective conservation requires consideration of both ecological priorities and the needs of human communities. The identification of CUZs is clearly focused on the latter, but they should not be interpreted as limiting conservation outcomes. There is also a need for more comprehensive biodiversity assessments in southern Suriname to complement the data produced through community mapping. The most effective conservation outcomes will protect biodiversity while meeting the needs of indigenous communities in the region. Large-scale resource development projects in the region pose a risk to both. An in-situ conservation strategy, operationalized through CUZ mapping, can provide a pragmatic pathway to achieve biodiversity protection while maintaining human well-being.

\section{Acknowledgements}

This work took place under the "South Suriname" project of Conservation International Suriname, sponsored by the Harbers Family Foundation. The development of this manuscript was financially supported by Tropenbos International Suriname and WWF Guianas. We thank the communities of Sipaliwini, Pelelutepu, Palumeu, Apetina and Kawemhakan for their participation. We are grateful with the village chief of Sipaliwini, Capitein Euka and the Granman Nowahé from Apetina, for their great support and trust. We thank the Conservation International Suriname team namely K. Gajapersard, L. Kensen, P. Miranda, Ch. Resomardono, R. Tjon, A. Tjon Sie Fat, A. Moredjo, for their support during data collection. We are thankful to S. Crabbe and C. Martínez for the GIS assistance. We thank M. Wright for his useful insights and comments to the manuscript. J. Burrough was the professional language editor of a near-final draft of the paper. We thank two anonymous reviewers and the journal editor for the constructive comments that made us improve, substantially, the manuscript.

\section{References}

Alexiades, M. N. (2013). Mobility and migration in indigenous amazonia: contemporary ethnoecological perspectives. Berghahn Books.

Andrade, G. S. M., \& Rhodes, J. R. (2012). Protected areas and local communities: an inevitable partnership toward successful conservation strategies? Ecology and Society, 17. http://www.ecologyandsociety.org/vol17/iss4/art14/

Arnot, C. D., Luckert, M. K., \& Boxall, P. C. (2011). What is tenure security? conceptual implications for empirical analysis. Land Economics, 87, 297-311.

Bagstad, K. J., Johnson, G. W., Voigt, B., \& Villa, F. (2013). Spatial dynamics of ecosystem service flows: a comprehensive approach to quantifying actual services. Ecosystem Services, 4, 117-125.

Baker, W. L. (1992). The landscape ecology of large disturbances in the design and management of nature reserves. Landscape Ecology, 7, 181-194.

Bánki, O., \& Aguirre, J. (2011). Mapping the unexplored forest of Suriname. In Report of a pilot study to develop a land cover and vegetation map for southern Suriname. University of Amsterdam and Conservation International Suriname.
Ban, N. C., Mills, M., Tam, J., Hicks, C. C., Klain, S., Stoeckl, N., et al. (2013). A social-ecological approach to conservation planning: embedding social considerations. Frontiers in Ecology and the Environ, 11, 194-202.

Batisse, M. (1982). The biosphere reserve: a tool for environmental conservation and management. Environmental Conservation, 9, 101-111.

Bennett, A. F. (2003). Linkages in the landscape: the role of corridors and connectivity in wildlife conservation, conserving forest ecosystems series. Gland, Switzerland: IUCN-the World Conservation Union.

Bennett, D. E., \& Sierra, R. (2014). Multi-scale dimensions of indigenous land tenure in the amazon. Human Ecology, 42, 551-563.

Berkes, F. (2012). Implementing ecosystem-based management: evolution or revolution? Fish and Fisheries, 13, 465-476.

Bernard, E., Barbosa, L., \& Carvalho, R. (2011). Participatory GIS in a sustainable use reserve in Brazilian Amazonia: implications for management and conservation. Applied Geography, 31, 564-572.

Brown, \& Reed. (2000). Validation of a forest values typology for use in national forest planning. Forest Science, 46, 240-247.

Brown, G. (2013). The relationship between social values for ecosystem services and global land cover: an empirical analysis. Ecosystem Services, 5, 58-68.

Brown, G., \& Fagerholm, N. (2014). Empirical PPGIS/PGIS mapping of ecosystem services: a review and evaluation. Ecosystem Services, 13, 119-133.

Brown, G. G., \& Pullar, D. V. (2012). An evaluation of the use of points versus polygons in public participation geographic information systems using quasi-experimental design and Monte Carlo simulation. International Journal of Geographical Information Science, 26, 231-246.

Brown, G. G., \& Reed, P. (2012). Social landscape metrics: measures for understanding place values from public participation geographic information systems (PPGIS). Landscape Research, 37, 73-90.

Brown, G., Weber, D., Zanon, D., \& de Bie, K. (2012). Evaluation of an online (opt-in) panel for public participation geographic information systems surveys. International Journal of Public Opinion Research, 24, 534-545.

Bryan, B. A., Raymond, C. M., Crossman, N. D., \& Macdonald, D. H. (2010). Targeting the management of ecosystem services based on social values: where, what, and how? Landscape and Urban Planning, 97, 111-122.

Campese, J. (Ed.). (2009). Rights-based approaches: exploring issues and opportunities for conservation. In. Bogor, Indonesia: Center for International Forestry Research.

Canasur Gold, 2014. New concessions fully registered in Suriname.

Carpenter, S. R., Mooney, H. A., Agard, J., Capistrano, D., DeFries, R. S., Díaz, S., et al. (2009). Science for managing ecosystem services: beyond the millennium ecosystem assessment. Proceedings of the National Academy of Science, 106, 1305-1312.

Chan, K. M. A., Shaw, M. R., Cameron, D. R., Underwood, E. C., \& Daily, G. C. (2006). Conservation planning for ecosystem services. PLoS Biology, 4, e379.

Chao, S. (2012). Forest peoples: numbers across the world. Forest Peoples Programme

Chapin, F. S., Carpenter, S. R., Kofinas, G. P., Folke, C., Abel, N., Clark, W. C., et al. (2010). Ecosystem stewardship: sustainability strategies for a rapidly changing planet. Trends in Ecology and Evolution, 25, 241-249.

Colchester, M. (2000). Self-determination or environmental determinism for indigenous peoples in tropical forest conservation. Conservation Biology, 14 1365-1367.

Colchester, M. (1998). Who will garrison the fortress? A reply to Spinage. Oryx, 32, 245-248.

Cowling, R. M., Egoh, B., Knight, A. T., O’Farrell, P. J., Reyers, B., Rouget, M., et al. (2008). An operational model for mainstreaming ecosystem services for implementation. Proceedings of the National Academy of Sciences, 105. 9483-9488.

Crossman, N. D., Burkhard, B., Nedkov, S., Willemen, L., Petz, K., Palomo, I., et al. (2013). A blueprint for mapping and modelling ecosystem services. Ecosystem Services, 4, 4-14

Cumming, G. S. (2011). Spatial resilience: integrating landscape ecology, resilience, and sustainability. Landscape Ecology, 26, 899-909.

Daily, G. C., Polasky, S., Goldstein, J., Kareiva, P. M., Mooney, H. A., Pejchar, L., et al. (2009). Ecosystem services in decision making: time to deliver. Frontiers in Ecology and the Environment, 7, 21-28.

De Groot, R. S., Alkemade, R., Braat, L., Hein, L., \& Willemen, L. (2010). Challenges in integrating the concept of ecosystem services and values in landscape planning, management and decision making. Ecological Complexity, 7, 260-272.

Dramstad, W., Olson, J. D., \& Forman, R. T. T. (1996). Landscape ecology principles in landscape architecture and land-use planning. Washington, DC., USA: Island Press.

Egoh, B., Rouget, M., Reyers, B., Knight, A. T., Cowling, R. M., van Jaarsveld, A. S., et al. (2007). Integrating ecosystem services into conservation assessments: review. Ecological Economics, 63, 714-721.

Fabricius, C., Folke, C., Cundill, G., \& Schultz, L. (2007). Powerless spectators, coping actors, and adaptive co-managers: a synthesis of the role of communities in ecosystem management. Ecology and Society, 12. http://www. ecologyandsociety.org.proxy.library.uu.nl/vol12/iss1/art29/

Fagerholm, N., Käyhkö, N., Ndumbaro, F., \& Khamis, M. (2012). Community stakeholders' knowledge in landscape assessments-mapping indicators for landscape services. Ecological Indicators, 18, 421-433.

Farina, A. (2000). Landscape ecology in action. Dordrecht: Springer Netherlands.

Fahrig, L. (2001). How much habitat is enough? Biological Conservation, 100, 65-74.

Fisher, B., Turner, R. K., \& Morling, P. (2009). Defining and classifying ecosystem services for decision making. Ecological Economics, 68, 643-653. 
Fisher, J. A., Patenaude, G., Giri, K., Lewis, K., Meir, P., Pinho, P., et al. (2014). Understanding the relationships between ecosystem services and poverty alleviation: a conceptual framework. Ecosystem Services, 7, 34-45.

Heemskerk, M., \& Delvoye, K. (2007). Trio baseline study: a sustainable livelihoods perspective on the Trio indignous peoples of south Suriname. Suriname: Amazon Conservation Team.

Heemskerk, M., Delvoye, K., Noordam, D., \& Teunissen, P. (2006). Wayana baseline study: a sustainable livelihood approach on the Wayana Indigenous peoples living around Puleowime (Apetina), Palumeu and Kawemhakan (Anapaike) in Southeast Suriname. Suriname: Amazon Conservation Team.

Kothari, A., Corrigan, C., Jonas, H., Neumann, A., Shrumm, H., Secretariat of the Convention on Biological Diversity, 2014. Recognizing and supporting territories and areas conserved by indigenous peoples and local communities: Global overview and national case studies. Secretariat of the Convention on Biological Diversity, ICCA, Consortium, Kalpavriksh and Natural Justice. Montreal, Canada. Technical Series no. 64, 160pp.

Larson, A. M., Barry, D., \& Ram Dahal, G. (2010). New rights for forest-based communities? Understanding processes of forest tenure reform. International Forest Review, 12, 78-96.

Lele, S., Wilshusen, P., Brockington, D., Seidler, R., \& Bawa, K. (2010). Beyond exclusion: alternative approaches to biodiversity conservation in the developing tropics. Current Opinion in Environmental Sustainability, 2, 94-100.

McLain, R., Poe, M., Biedenweg, K., Cerveny, L., Besser, D., \& Blahna, D. (2013). Making sense of human ecology mapping: an overview of approaches to integrating socio-spatial data into environmental planning. Human Ecology, 41, 651-665.

Millennium Ecosystem Assessment. (2005). Ecosystems and human well-being: general synthesis: a report of the Millennium Ecosystem Assessment. Washington, DC: Island Press.

Miranda, C., Vadillo, A., 2012. Recognition and support of ICCA's in Bolivia. In: Kothari, A. 2014. Recognizing and supporting territories and areas conserved by indigenous peoples and local communities: Global overview and national case studies. Secretariat of the Convention on Biological Diversity, ICCA, Consortium, Kalpavriksh, and Natural Justice, Montreal, Canada. Technical Series no. 64, 160pp.

Nassauer, J. I., \& Opdam, P. (2008). Design in science: extending the landscape ecology paradigm. Landscape Ecology, 23, 633-644.

Opdam, P., \& Wascher, D. (2004). Climate change meets habitat fragmentation: linking landscape and biogeographical scale levels in research and conservation. Biological Conservation, 117, 285-297.

Oviedo, G. (2006). Community conserved areas in South America. Parks, 16, 49-55.

Pagella, T. F., \& Sinclair, F. L. (2014). Development and use of a typology of mapping tools to assess their fitness for supporting management of ecosystem service provision. Landscape Ecology, 29, 383-399.

Palomo, I., Martín-López, B., Potschin, M., Haines-Young, R., \& Montes, C. (2013). National parks, buffer zones and surrounding lands: mapping ecosystem service flows. Ecosystem Services, 4, 104-116.

Pérez-Llorente, I., Paneque-Gálvez, J., Luz, A. C., Macía, M. J., Guèze, M., Domínguez-Gómez, J. A., et al. (2013). Changing indigenous cultures, economies and landscapes: the case of the Tsimane', Bolivian Amazon. Landscape and Urban Planning, 120, 147-157.

Persha, L., Agrawal, A., \& Chhatre, A. (2011). Social and ecological synergy: local rulemaking, forest livelihoods, and biodiversity conservation. Science, 331, 1606-1608.

Poppy, G. M., Chiotha, S., Eigenbrod, F., Harvey, C. A., Honzak, M., Hudson, M. D., et al. (2014). Food security in a perfect storm: using the ecosystem services framework to increase understanding. PhilosophicalTransactions of the Royal Society. B Biological Sciences, 369, 20120288.

Poppy, G. M., Jepson, P. C., Pickett, J. A., \& Birkett, M. A. (2014). Achieving food and environmental security: new approaches to close the gap. Philosophical Transactions of the Royal Society B Biological Sciences, 369, 20120272.
Porter-Bolland, L., Ellis, E. A., Guariguata, M. R., Ruiz-Mallén, I. Negrete-Yankelevich, S., \& Reyes-García, V. (2012). Community managed forests and forest protected areas: an assessment of their conservation effectiveness across the tropics. Forest Ecology and Management, 268, 6-17.

Ramirez-Gomez, S. O. I., Brown, G. G., \& Tjon Sie Fat, A. (2013). Participatory mapping with indigenous communities for conservation: challenges and lessons from suriname. Electronic Journal of Information System in Developing Countries., 58, 1-22

Ramirez-Gomez, S. O. I., \& Martínez, C. (2013). Participatory GIS: indigenous communities in Suriname identify key local sites. ESRI, 35, 22.

Ramirez-Gomez, S. O. I., Torres-Vitolas, C. A., Schreckenberg, K., Honzák, M., Cruz-Garcia, G. S., Willcock, S., et al. (2015). Analysis of ecosystem services provision in the Colombian Amazon using participatory research and mapping techniques. Ecosystem Services, 13, 93-107.

Raudsepp-Hearne, C., Peterson, G. D., \& Bennett, E. M. (2010). Ecosystem service bundles for analyzing tradeoffs in diverse landscapes. Proceedings of the National Academy of Sciences, 107, 5242-5247.

Rempel, R., \& Carr, A. (2012). Patch analyst and patch grid. In Ontario ministry of natural resources. Thunder Bay, Ontario: Centre for Northern Forest Ecosystem Research.

Reyers, B., Biggs, R., Cumming, G. S., Elmqvist, T., Hejnowicz, A. P., \& Polasky, S. (2013). Getting the measure of ecosystem services: a social-ecological approach. Frontiers in Ecology and the Environment, 11, 268-273.

Schägner, J. P., Brander, L., Maes, J., \& Hartje, V. (2013). Mapping ecosystem services' values: current practice and future prospects. Ecosystem Services. Special Issue on Mapping and Modelling Ecosystem Services, 4, 33-46.

Schwartzman, S., \& Zimmerman, B. (2005). Conservation alliances with indigenous peoples of the Amazon. Conservation Biology, 19, 721-727.

Serna-Chavez, H. M., Schulp, C. J. E., van Bodegom, P. M., Bouten, W., Verburg, P. H., \& Davidson, M. D. (2014). A quantitative framework for assessing spatial flows of ecosystem services. Ecological Indicators, 39, 24-33.

Sherrouse, B. C., Clement, J. M., \& Semmens, D. J. (2011). A GIS application for assessing, mapping, and quantifying the social values of ecosystem services. Applied Geography, 31, 748-760.

Suriname Business Forum, 2010. Renewable energy potential and business opportunities in Suriname.

Syrbe, R.-U., \& Walz, U. (2012). Spatial indicators for the assessment of ecosystem services: providing, benefiting and connecting areas and landscape metrics. Ecological Indicators, 21, 80-88.

Termorshuizen, J. W., \& Opdam, P. (2009). Landscape services as a bridge between landscape ecology and sustainable development. Landscape Ecology, 24, 1037-1052.

Tischendorf, L., \& Fahrig, L. (2000). On the usage and measurement of landscape connectivity. Oikos, 90, 7-19.

VIDS, 2012. Recognition and support of ICCAs in Suriname. In: Kothari, A. 2014 Recognizing and supporting territories and areas conserved by indigenous peoples and local communities: global overview and national case studies. Secretariat of the convention on biological diversity, ICCA, Consortium, Kalpavriksh, and Natural Justice, Montreal, Canada. Technical Series no. 64, 160pp.

Villa, F., Voigt, B., \& Erickson, J. D. (2014). New perspectives in ecosystem services science as instruments to understand environmental securities. PhilosophicalTransactions of the Royal Society. B Biological Sciences, 369, 20120286.

Willemen, L., Drakou, E. G., Dunbar, M. B., Mayaux, P., \& Egoh, B. N. (2013). Safeguarding ecosystem services and livelihoods: understanding the impact of conservation strategies on benefit flows to society. Ecosystem Services, 4 95-103.

Williams, J. C., ReVelle, C. S., \& Levin, S. A. (2005). Spatial attributes and reserve design models: a review. Environmental Modelling and Assessment, 10, 163-181. 